TITLE:

\title{
OSTRACOD FAUNA OF THE INTERTIDAL ZONE IN THE VICINITY OF THE SETO MARINE BIOLOGICAL LABORATORY
}

AUTHOR(S):

Schornikov, E.I.

\section{CITATION:}

Schornikov, E.I.. OSTRACOD FAUNA OF THE INTERTIDAL ZONE IN THE VICINITY OF THE SETO MARINE BIOLOGICAL LABORATORY. PUBLICATIONS OF THE SETO MARINE BIOLOGICAL LABORATORY 1975, 22(1-4): 1-30

\section{ISSUE DATE:}

1975-07-31

URL:

http://hdl.handle.net/2433/175892

RIGHT: 


\title{
OSTRACOD FAUNA OF THE INTERTIDAL ZONE IN THE VICINITY OF THE SETO MARINE BIOLOGIGAL LABORATORY ${ }^{1)}$
}

\author{
E. I. SCHORNIKOV \\ Hydrobiological Laboratory, Institute of Marine Biology of the Far Eastern \\ Scientific Center of the Academy of Sciences, Vladivostok, USSR
}

With Text-figures $1-15$

There are known 130 ostracod species from the coast of Japan (Hanai, $1959 \mathrm{~b}$, 1970; Benson, 1964; Ishizaki, 1968, 1969, 1971), but from the region of the Seto Marine Biological Laboratory so far has never been recorded formally even one species of these crustaceans.

In February 1971 Dr. A.V. Zhirmunsky had collected from the rocky intertidal zone near the Seto Marine Biological Laboratory clusters of some mytilids mingled with fine algae and a quantity of sand and submitted those to the author's disposal. Among the rest of these molluscs there were found 20 ostracod species of 11 genera; 5 of these species are new to the region of the Seto Marine Biological Laboratory, one is new to the coasts of Japan and 14 are new to science. On the basis of this material are described 2 new genera and is separated one new subfamily of Ostracoda.

The author is very much obliged to Dr. Zhirmunsky for his generosity in submitting the material to the author and also to Prof. T. Tokioka for his kindness in taking editorial troubles.

In the generic description are adopted the following codes and abbreviations to show the feature of appendages:



$$
\begin{aligned}
& \text { D -dorsal, } \\
& \text { d -distal, } \\
& \text { v -ventral, } \\
& \text { l - lateral, } \\
& \text { m -medial. }
\end{aligned}
$$

In figures are given the following captions:

$$
\begin{aligned}
& \text { h - hingement, } \\
& \text { AI -antennule, } \\
& \text { AII - antenna, } \\
& \text { Ex -exopodite (or palp), } \\
& \text { Md -mandible, }
\end{aligned}
$$

$$
\begin{array}{ll}
\text { v } & \text {-vibratory plate, } \\
\text { PI-PII - thoracopods I-II, } \\
\text { Pe - copulatory organ, } \\
\text { R-L - - right-left, } \\
\text { bo - brush-shaped organ, }
\end{array}
$$

1) Contributions from the Seto Marine Biological Laboratory, No. 597.

Publ. Seto Mar. Biol. Lab., XXII (1/4), 1-30, $1975 . \quad$ (Article 1) 


$$
\begin{array}{ll}
\text { MxI -maxillula, } & a b \text {-abdomen, } \\
\text { MxII -maxilla, } & \text { F -furca. }
\end{array}
$$

All holotypes are deposited in the collection at the Institute of Marine Biology.

\section{Systematic Description}

Order Podocopida Müller, 1894

Family Bairdiidae Sars, 1888

Genus Neonesidea Maddox, 1969

\section{Neonesidea oligodentata (Kajiyama)}

Bairdia oligodentata: Kajiyama, 1913, p. 3, pl. 1, figs. 10-18. Ishizaki, 1968, p. 16; pl. 1, figs. 1,2; pl. 3, figs. 1-3.

Material: Left shell 0,94 mm long and 6 shells of instars A-3-A-5.

Distribution: Shallow waters of Japan: Prefectures Kanagawa (Misaki) and Kochi (Uranouchi Bay).

Family Cytheridae Baird, 1850

Subfamily Krithinae Mandelstam in Bubikan, 1958

Genus Eukrithe Schornikov, gen. n.

Type species: Eukrithe zhirmunskyi Schornikov, sp. n.

Diagnosis: Carapace small, subtriangular. Hingement pseudadont, with crenulated middle and posterior parts of selvage of right shell. Zone of concrescence is very narrow, with short and wide radial canals, normal pore canals are large, simple. Ventral seta of the second podomere of antennal endopodite as a large oval plate. Basal part of mandible with a serrated posterior margin. One of dorsodistal setae of basal podomere of maxilla is extremely large, the other one is rudimentary.

Description: Carapace thin, smooth; the anterior margin is widely rounded; the posterior margin bluntly pointed; it looks oval-rectangular when seen from the dorsal side. The inner margin is running near and in parallel with the external margin and is separated from line of concrescence all through. There are 4 adductor scars, arranged in a vertical row; frontal scar rounded, very large, and situated at the level of upper two adductor scars; mandibular scar very small and situated a little lower and in front of lower adductor scar.

Antennule 5-segmented, robust, and armed as III: $1 \mathrm{sDd}, \mathrm{IV}: 1 \mathrm{svd}, 1 \mathrm{sim}, 1$ $\mathrm{sDm}, 1 \mathrm{cDm}, 1 \mathrm{sDd}, 1 \mathrm{cDd}, \mathrm{V}: 2 \mathrm{c}, 1$ ts.

Antenna very robust. Exopodite 2-segmented, its basal part with a sign of one more suture in the middle. Endopodite 3-segmented and armed as I: 1 svd, II: 2 svm, 1 svd, 2 sDm, III: 3 c.

Mandible with robust basal part. Masticatory surface with 7 dents, 2 to 4 of them serrated, and 3 setae situated respectively near the first and second dents and 
behind the dental row. The posterior margin with 4 serrations. Vibratory plate with 3 (?) rays, one of them rudimentary. Palp 4-segmented, the second podomere elongated and the third short and very extended. It is armed as I: 2 svd, 1 sld, II: 1 svd, 2 sld, III: 2 svd, 1 cld, 6 sDd, IV: 3 c, 1 s.

Maxillula with vibratory plate with 15 rays of a similar structure. Basal podomere of palp with 4 dorsal and 1 ventral setae, the terminal podomere with 3 apical setae. There are 3 masticatory lobes, each with 6 apical setae; ventromedial seta

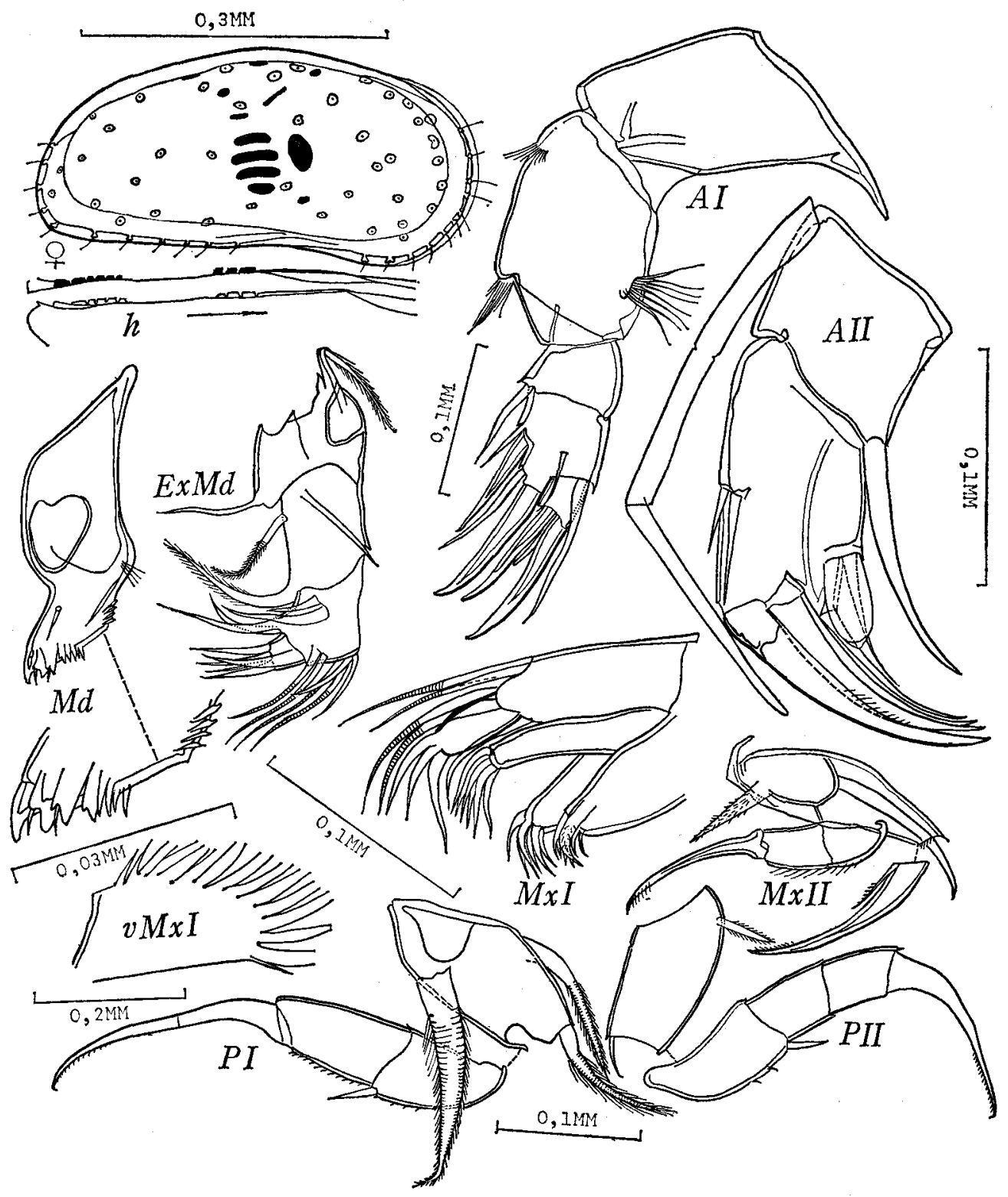

Fig. 1. Eukrithe zhirmunskyi, sp. n. 
of posterior lobe large and plumose.

Maxilla and thoracopod I 3-segmented, thoracopod II 4-segmented; setal formula of their basal podomere is 121/111/011; apical clwas thin, long, and weakly curved. Two distal podomeres of maxilla are very short and the suture between them is hardly noticed, the second podomere without ventrodistal seta.

Furca with 2 thick, long setae.

Remarks: The morphology of the new genus corresponds to that of the subfamily Krithinae (Hartmann, 1963), especially more closely to that of Parakrithella, but the new genus is well distinguished from them by the form of the carapace, structures of the hingement and concrescence zone, and some other details of appendage structure.

\section{Eukrithe zhirmunskyi Schornikov, sp. n.}

(Fig. 1)

Holotype: Female, preparations No. 492-493.

Material: One female $0,42 \mathrm{~mm}$ long, one of instar A-5 and 5 shells of instars A-1-A-4.

Description: Garapace is highest slightly anterior to the middle and there almost half as high as long. The anterior margin widely and evenly rounded; the dorsal margin weakly convex, being gently lowered from the highest point down to anterior and posterior margins; the posterior margin cut off from above, narrowly rounded and passing to the ventral margin with an obtuse angle between; the ventral margin straight in the posterior half but weakly concave slightly anterior to the middle.

Length ratio between distal podomeres of antennule is $40: 15: 14: 17$. Length ratio between endopodite podomeres of antenna $5: 7: 1$, seta of the first podomere longer than the second podomere by $1 / 3$ of the length of the latter, simple ventromedial seta of the second podomere extending over its distal margin by $1 / 2$ of the span of the podomere and ventrodistal seta a little shorter than apical claws. The greater of dorsodistal setae of maxilla 3,5 times as long as the lesser one and as long as the basal podomere; the corresponding seta of the first thoracopod gentle, plumose, and 8: 11 in length as compared with the basal podomere; the same of thoracopod II very small.

Subfamily Cytherinae Baird, 1850

Genus Cythere O.F. Müller, 1785

\section{Cythere omotenipponica Hanai}

Cythere lutea omotenipponica: Hanai, 1959a, p. 413; pl. 28, figs. 5a-b; 1970, p. 710-715; figs. 10 A,E; $11 \mathrm{~A}, \mathrm{E}, \mathrm{J} ; 12 \mathrm{~A} ; 13 \mathrm{~B}, \mathrm{D}, \mathrm{D}^{\prime}, \mathrm{F}, \mathrm{H}, \mathrm{H}^{\prime}$. Ishizaki, 1966, p. 137; pl. 17, figs. 9-12; 1968, p. 16; pl. 3, figs. 7,8 .

Material: Right shell of a $0,6 \mathrm{~mm}$ long female. 
Remarks: C. omotenipponica is an independent species, as it is distinguishable from Cythere lutea O.F. Müller, 1785 by the form of the copulatory organ in male and by the form of the genital lobe in female.

Distribution: Southeastern coasts of Japan: Prefectures Kanagawa and Kochi (Uranouchi Bay), in the Miocene deposits of Sendai area as fossils.

\section{Genus Schizocythere Triebel, 1950}

\section{Schizocythere kishinouyei (Kajiyama)}

Cythere kishinouyei: Kajiyama, 1913, p. 11; pl. 1, figs. 61-63.

Schizocythere kishinotyei (Kajiyama): Hanai, 1961, p. 369; text-fig. 11. figs. 3a, b; 1970, p. 696-723; pl. 107, fig. 3; text-figs. 3, 4, 10 B, F; 11 B, F, F', K; 12 B, 13 A, 19. Ishizaki, 1968, p. 38; pl. 9, figs. 15,16 .

Material: One shell of instar A-1.

Distribution: Pacific coasts of Japan: Prefectures Kanagawa and Kochi (Uranouchi Bay).

\section{Subfamily Loxoconchinae Sars, 1925 \\ Genus Loxoconcha Sars, 1866}

\section{Loxoconcha japonica Ishizaki}

Loxoconcha japonica: Ishizaki, 1968, p. 28; pl. 2, fig. 1; pl. 6, figs. 10-12.

Material: Two female shells, $0,5 \mathrm{~mm}$ long.

Distribution: Japan, Prefecture Kochi (Uranouchi Bay).

\section{Loxoconcha sp.}

Loxoconcha sp. A: Ishizaki, 1968, p. 34; pl. 7, figs. 4, 5.

Material: Right shell of a 0,49 mm long female and 3 shells of instars A-2-A-4.

Distribution: Japan, Prefecture Kochi (Uranouchi Bay).

\section{Subfamily Xestoleberinae Sars, 1928 \\ Genus Xestoleberis Sars, 1866}

\section{Xestoleberis ishizakii Schornikov, sp. $\mathrm{n}$.}

(Fig. 2)

Xestoleberis sagamiensis Kajiyama: Ishizaki, 1968, p. 42; pl. 9, figs. 3, 4; 1971, p. 95; pl. 4, fig. 11. (non Kajiyama, 1913)

Holotype: Male, preparations No. 494-495.

Material: 3 males $0,40-0,42 \mathrm{~mm}$ long, 10 females $0,40-0,46 \mathrm{~mm}$ long, one of 
instar A-4 and 3 shells.

Description: Male. Carapace is rounded in a kidney-shape, strongly inflated, highest and widest at the level of posterior third, where it is $2 / 3$ as high as long. In dorsal view, the anterior end of carapace weakly pointed, while the posterior narrowly rounded. The anterior margin clearly cut off from above, broadly rounded in the lower part; the dorsal margin strongly convex, its posterior half and the posterior margin form together nearly a right semicircle; the ventral margin faintly concave, forming an obtuse angle between it and the posterior margin. Left shell slightly

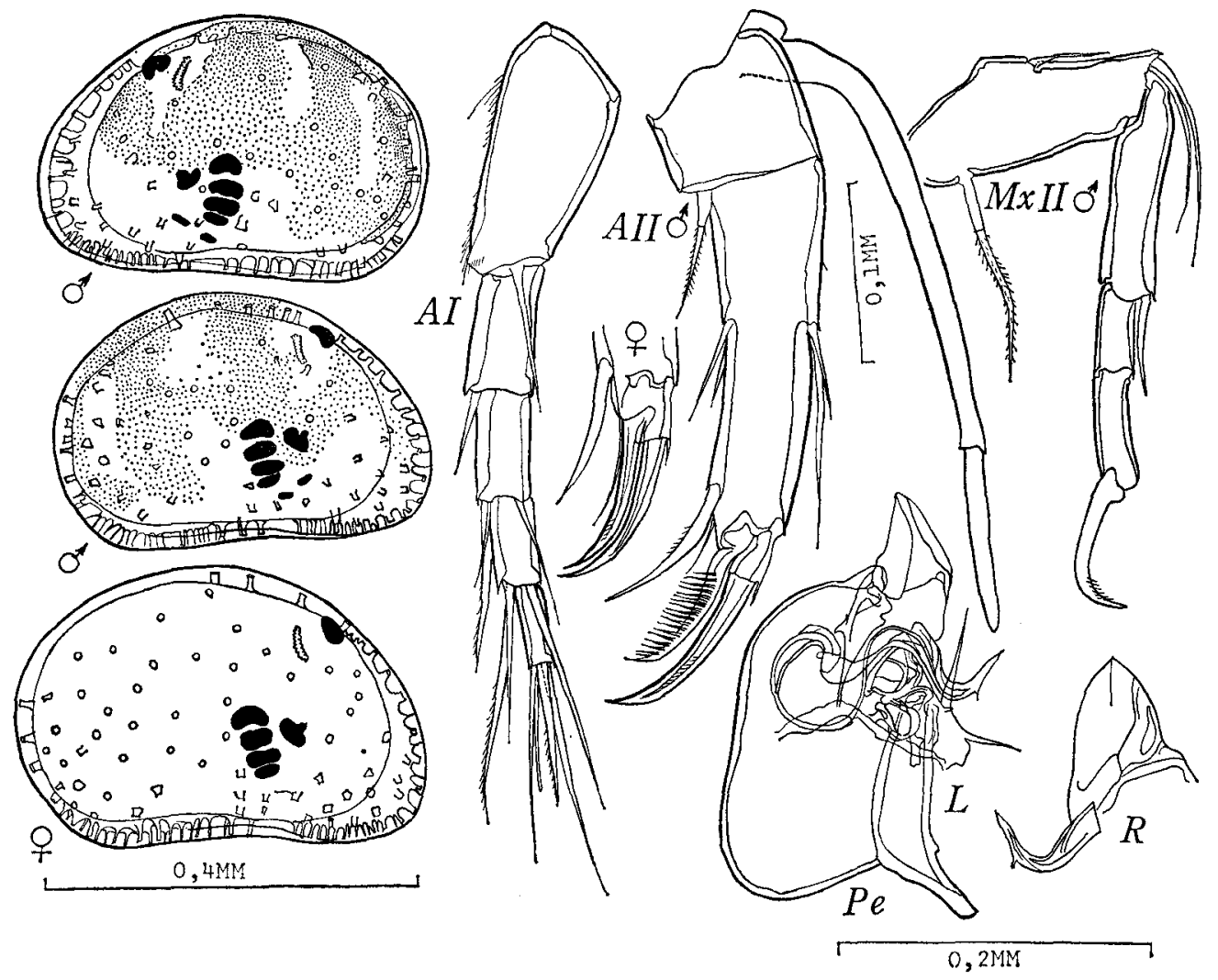

Fig. 2. Xestoleberis ishizakii, sp. n.

more rounded than right one. Radial pore canals in the upper part of anterior and posterior margins sparse, short and wide, while in the lower part dense and narrow. Normal pore canals sparse and large. Frontal muscle-scar heart-shaped, "Xestoleberis spot" narrow and semilunar.

Colour light brown, strongly greenish opalescent and with 4 large dark brown transversal patches.

Length ratio between distal podomeres of antennule is $35: 20: 16: 15: 12$, ventrodistal seta of the second podomere a little longer than the third; dorsodistal seta 
of the third podomere thin, falling short of the end of the fourth; one of dorsodistal setae of the fourth podomere thick and reaching the end of the terminal podomere, while the other thin and never reaching beyond the base, ventrodistal seta reaching the middle of the last podomere. The terminal podomere with 4 setae, one of them claw-shaped.

Length ratio between endopodite podomeres of antenna is $4: 5: 6: 2$, ventrodistal seta of the first podomere reaches the end of the second podomere, the largest of ventrodistal setae of the second podomere is $3 / 5$ the length of the ventral margin of the third podomere. Inner apical claw of endopodite is pectinate and reaches the level of the distal fouth of stout, weakly curved outer claw.

Masticatory part of mandible with 7 dents (second to sixth serrated) and 4 setae, one of them situated behind the anterior dent and three others behind the dental row. Vibratory plate with 2 long and one rudimentary rays. Penultimate podomere of palp with 2 dorsomedial setae, one of them rudimentary; terminal podomere with 3 apical setae, one of them claw-shaped.

Setal formula of basal podomere of maxilla and thoracopods is $121 / 111 / 111$. Dorsodistal setae of basal podomere of maxilla thin, lesser one is $2 / 3$ as long as the second podomere, while larger one almost reaches its end. Apical claw of maxilla and thoracopods stout, straight at the proximal part, but sharply curved and with a row of hairs at the distal part.

Female. Carapace shape roughly similar to male, but more angular and the ventral margin a little more concave; the angle between the ventral and posterior margins more distinct. In the dorsal view, the posterior end rounded considerably more widely than in male.

Inner apical claw of antenna not pectinate and reaching the end of outer claw. Shorter dorsodistal seta of the basal podomere of maxilla about $1 / 3$ as long as longer one and reaching the middle of the second podomere.

Remarks: This species has ever been found by Ishizaki (1968), from Uranouchi Bay (Kochi Prefecture) and at that time identified with Xestoleberis sagaminensis Kajiyama, 1913. However, this species differs from $X$. sagaminensis in having more widely rounded posterior margin, blunt angle between the posterior and ventral margins of shell, thinner and pointed ventrodistal seta on the penultimate podomere of antenna, and shorter copulatory tube furnished with serration on the external margin.

\section{Xestoleberis dentata Schornikov, sp. n.}

(Fig. 3)

Holotype: Male, preparations No. 496-497.

Material: 3 males 0,39-0,40 mm long, 4 females 0,42-0,43 $\mathrm{mm}$ long, 2 females $0,49 \mathrm{~mm}$ long; one shell of female and one shell of instar A-1.

Description: Male. Carapace elongated kidney-shaped, weakly inflated; highest and widest in the middle part; height a little more than a half of length, and 
width half as large as shell length. The anterior margin weakly cut off from above, narrowly rounded in the lower part; the dorsal margin evenly convex; the posterior margin rounded widely and evenly; the ventral margin distinctly concave near mouth and with a small angle in front of it. Flange of left shell with 5-6 dents between the anterior and ventral margins and 8-12 ones in the posterior part of the ventral margin;

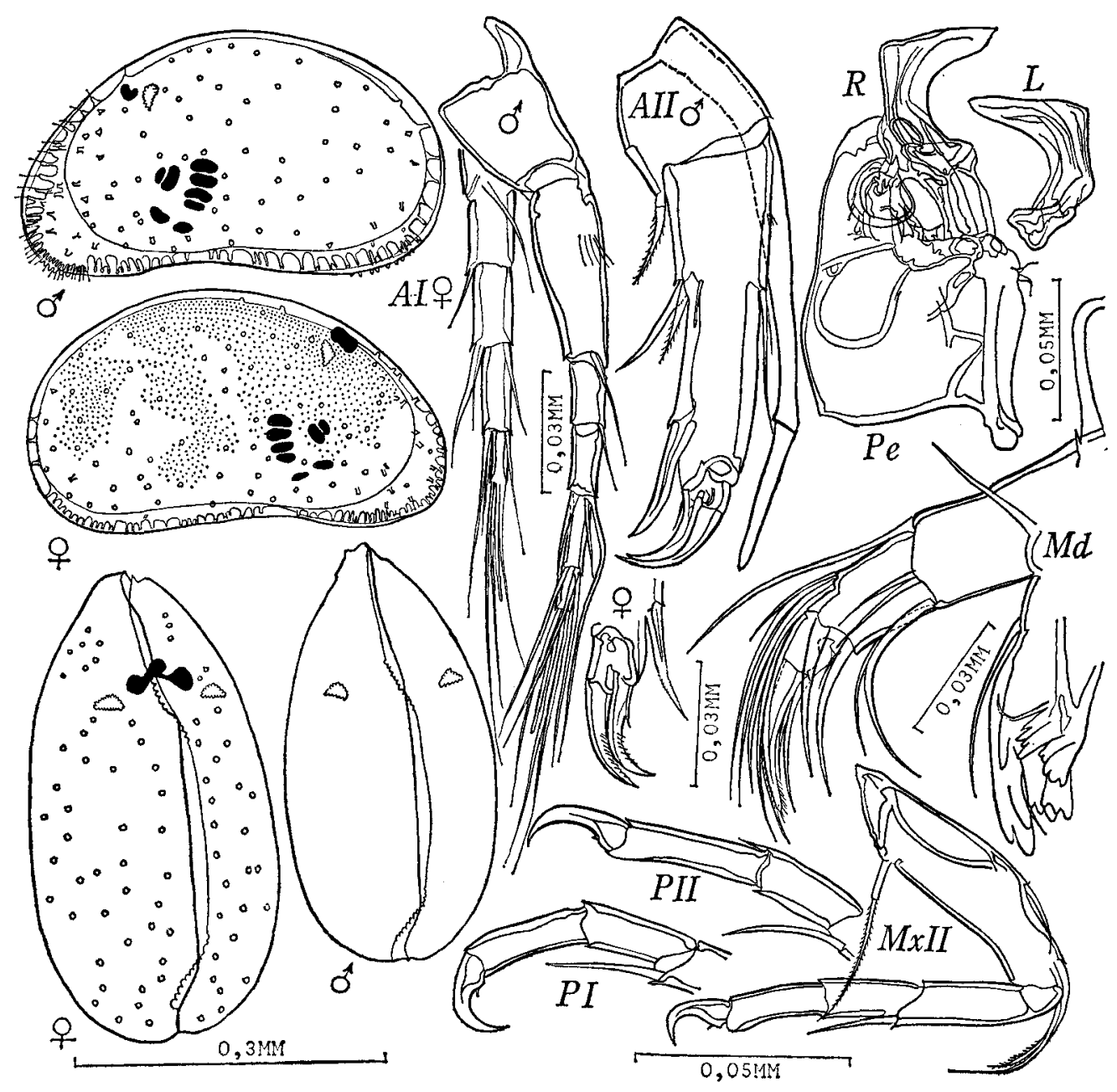

Fig. 3. Xestoleberis dentata, sp. n.

right shell without any of these dents. In the dorsal view, shell elongate-oval, with the anterior end bluntly pointed, the posterior end narrowly rounded and with an excavation at the junction of shells. There is an acute anterior prominence on left shell. Radial pore canals short, dense and thinner in the anteroventral region, but sparse and thicker in other parts of pore canal zone. Normal pore canals small, rather dense. Frontal muscular scar consists of 2 elements. "Xestoleberis spot" large, 
triangular.

Colour yellow-orange, with 3 large, brown transversal spots.

Length ratio between distal podomeres of antennule is $35: 10: 12: 15: 7$; all setae thin, the laterodistal seta on the second podomere reaches the middle of the fourth podomere, the seta of the third podomere nearly reaches the tip of the fourth podomere, the larger dorsodistal seta of the fourth podomere very long, while the other shorter one only a little exceeding the penultimate podomere, and the ventrodistal seta of the same podomere reaches the middle of the terminal podomere furnished with very long apical setae.

Length ratio between endopodite podomeres of antenna is $24: 25: 33: 7$, the ventrodistal seta of the first podomere reaches the tip of the second podomere, the larger ventrodistal seta of the second podomere is $3 / 5$ as long as the ventral margin of the third podomere, the ventrodistal seta of the third podomere stout, claw-shaped, but weakly curved. Apical claws of antenna are almost equal to each other; smooth, short, and strongly curved.

Masticatory part of mandible with 7 serrated dents and 2 setae, one just behind the first dent and the other far behind the dental row. Vibratory plate with a long ray and another rudimentary one. The penultimate podomere of palp with 4 dorsomedial, one laterodistal and 2 ventrodistal setae, one of the last is rudimentary; the terminal podomere with 4 apical setae, inclusive of a claw-shaped one plumose at the end.

Setal formula of the basal podomere of maxilla and thoracopods is $121 / 111 / 111$. Apical claw of these appendages short, thick, strongly curved, and with a spinule at the base.

Female. Shape of carapace is similar to male, though in dorsal view it is weakly inflated that the lateral contours are nearly parallel in the middle part, and the acute prominence near the anterior end of left shell is missing.

The larger dorsodistal seta of the fifth podomere of antennule thickened, but only reaching the tip of the terminal podomere, and ventrodistal seta of the same podomere only attaining the base of the last podomere. Ventrodistal seta of endopodite penultimate podomere of antenna thicker than in male and with a sharply pointed end, apical claws of antenna curved more weakly and each with a row of hairs.

Remarks: The present new species is related to Xestoleberis eulittoralis Hartmann, 1959 , but distinguished from the latter by the shape of copulatory organ.

\section{Subfamily Cobanocytherinae Schornikov, subfam. n.}

Type genus: Cobanocythere Hartmann, 1959.

Description: Carapace small, smooth, compressed dorsoventrally and with plane ventral side which is evenly concave in the posterior part. Hingement rectodont, lophodont, or hemimerodont. Zone of concrescence wide, often with branched radial pore canals. Inner margin and zone of concrescence usually separated. 
Normal pore canals simple or of the sieve-type. Adductor scars only 3, fulcral; single or double frontal and 2 mandibular scars. Eye single.

Antennule 5- or 6-segmented, sometimes the fourth and fifth united; 3 apical setae united one another at the base forming the tiny false seventh podomere. The second podomere with a ventrodistal seta. Exopodite of antenna long, equally developed in both sexes. Endopodite with an apical claw and a seta or the rudimentary second claw, the second podomere with a ventrodistal seta.

Masticatory part of mandible with anterior dent considerably larger than the others; palp 4-segmented, narrow, without vibratory plate.

In maxillula, palp and masticatory lobes show a tendency to reduce, vibratory plate with a small number of similar rays.

Maxilla with 2 dorsodistal setae on the basal podomere. Brush-shaped organ cylindrical, with a bundle of apical setae of unequal lengths, furca with one or two setae.

Remarks: Cobanocythere Hartmann, 1959, Microcytheridea Hartmann, 1965, and Platymicrocythere Schornikov, gen. $\mathrm{n}$. are referred to the new subfamily. This specialized group is adapted to the interstitial life on bottoms sandy, pebbly or covered with cockle-shells. According to the habitus of inhabitting the similar biotopes, the group is in convergence with Microcytherinae and Parvocytherinae.

Hartmann (1959, 1963) provisionally referred the genus Cobanocythere to the subfamily Microcytherinae, though supposing the convergence between the genus and subfamily. Really, they conform to each other only in the shape of carapace, but Cobanocythere is distinguished from Microcythere in other most important features such as triple scars of adductor, the second podomere of antennal endopodite with a single ventrodistal seta, mandible without vibratory plate, basal podomere of maxilla with 2 dorsodistal setae, and the existence of furca.

Genus Microcytheridea Hartmann, 1965 may be referable to the subfamily Cytherideinae, so far as the existence of pore canals of the sieve-type and the peculiar structure of the first thoracopod of male similar to that of Pontocythere Dybowsky, 19391) are regarded as definitive, but in other features Microcytheridea is sharply distinguished from all genera of Cytheridae. Moreover, as it was shown by Omastola (1970), the structure of pore canals is very variable in Cytheridae and cannot be an important criterion, at least for separating large taxonomical categories, and the sexual dimorphism in the structure of the first thoracopod is typical not only for Cytherideinae, but also for some of Trachyleberidinae (Buntonia Howe, 1935) and Cytherominae (Pontocytheroma Marinov, 1963).

Genus Cobanocythere Hartmann, 1959

9. Cobanocythere? japonica Schornikov, sp. n.

(Fig. 4)

1) Recently, genus Pontocythere is referred to the subfamily Krithinae (Caraion, 1967). 
Holotype: Male, preparations No. 498-499.

Material: 5 males $0,23-0,25 \mathrm{~mm}$ long and 6 females $0,25-0,26 \mathrm{~mm}$ long.

Description: Male. Carapace moderately compressed dorsoventrally. Ratio between length, height and width is 18:9:8. The anterior margin of left shell indistinctly cut off from above, narrowly rounded and with a noticeable angle before it continues to the ventral margin; the dorsal margin nearly straight; the posterior margin obliquely truncate in the upper part but narrowly rounded in the lower part

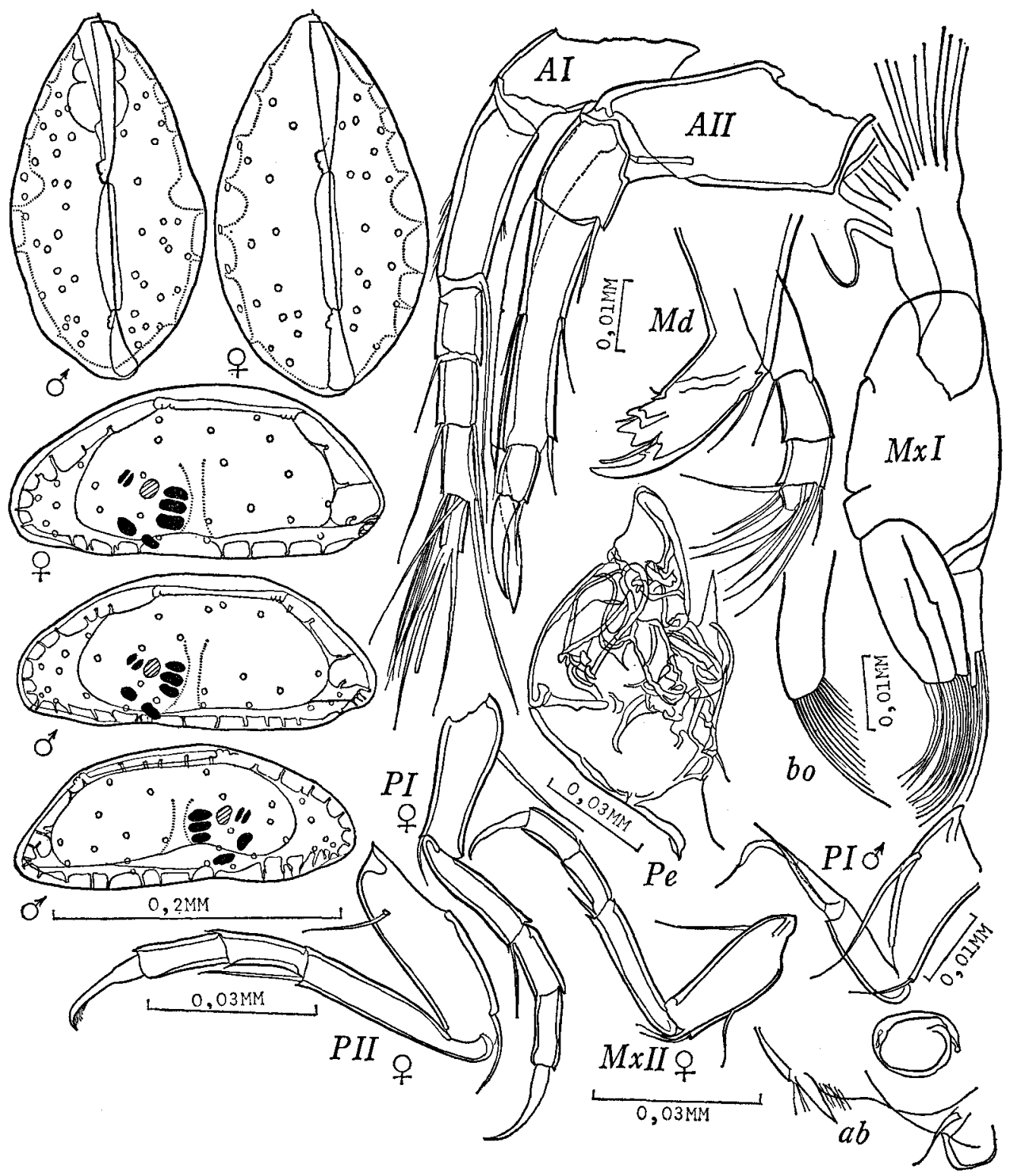

Fig. 4. Cobanocythere? japonica, sp. n. 
and with a gentle excavation on the border with the ventral margin which forms a weak angle in the posterior part, a feeble concavity near mouth and a smooth prominence before it. Right shell lower and shorter than the left, and angular. The anterior margin more narrowly rounded, and without angle on the border with the ventral margin; the dorsal margin straight, cardinal angles rounded, but distinct; the posterior margin forming a large angle with the tip in the lower part; the ventral margin straight and with a large prominence before mouth. In the dorsal view, carapace nearly subellipsoidal, with weakly pointed anterior and narrowly rounded posterior ends, with a gentle impression slightly before the middle on right shell, and with weakly expressed angles in the middle and posterior parts in the posterior half of left shell at the level of posterior $1 / 6$ of the length. Hingement hemimerodont; anterior tooth of right shell with two, and posterior one with 3 weak crenulations. In the middle part just behind adductor scars, the shell wall is strongly thickened and forms on the inner surface a transversal elevation. Radial pore canals sparse, mostly simple, poorly branched only in the anterior part of the ventral and in the lower part of the posterior margins. Normal pore canals large, simple (?).

Carapace transparent, body with irregular patterns of brown pigment spots.

Antennule 6-segmented and armed as follows: II, 1 svd; III, 1 sDd; IV, 1 svd; $1 \mathrm{sDd} ; \mathrm{V}, 1 \mathrm{svd}, 1 \mathrm{sld}, 2 \mathrm{sDd} ; \mathrm{VI}, 3 \mathrm{~s}, 1$ ts. Length ratio between distal podomeres is $9: 3: 3: 3: 2$, the seta of the second podomere slightly exceeding the fifth podomere, and the seta of the third podomere considerably shorter than that of the fourth podomere.

Exopodite of antenna 2-segmented, the proximal part with a sign of an articulation. Endopodite 4-segmented, length ratio of podomeres is $4: 5: 6: 2$, the seta by apical claw thin and $2 / 3$ as long as the latter.

Masticatory part of mandible with 5 dents and 3 setae. Anterior dent smooth, with a small prominence at the base; 2 to 4 dents serrated; the fifth dent small and conical; setae respectively one at the base of the first, second and fifth dents. Basal podomere of mandibular palp with a ventrodistal seta; the third podomere with 3 dorsodistal setae, 2 longer and 1 shorter ones, a single laterodistal and 2 ventrodistal setae; the terminal podomere very small and triangular, with 3 setae inclusive of a claw-shaped one.

Maxillula with 3 masticatory lobes furnished with long setae; palp 2-segmented, the basal podomere with 2 (?) long dorsodistal setae, while the distal one rudimentary, thin, and with a single (?) seta. Vibratory plate with 10 rays.

Setal formula of basal podomeres of maxilla and thoracopods is 121/011/011; thoracopod I with 2 underdeveloped, soft distal podomeres. Apical claw of maxilla and 2 thoracopods thin, weakly curved.

Female. Carapace somewhat wider than in male; ratio between length, height and width is 19:9:11. Anterior and posterior margins of left shell rounded more widely than in male, no excavation definable between the posterior and ventral margins, the dorsal margin smoothly convex. Prominence in the anterior part of the ventral margin of right shell larger than in male. In the dorsal view, shell suboval 
and smoothly inflated laterally, the anterior end obtusely pointed and the posterior end widely rounded.

First thoracopod normal. Furca with 2 setae, one twice as long as the other.

Remarks: There are known 4 species, referred to the genus Cobanocythere: subterranea Hartmann, 1959 and labiata Hartmann, 1959 from the Pacific coast of Central America (Hartmann, 1959) and hartmanni Reys, 1961 and Cobanocythere ? sp. from the Mediterranean Sea (Reys, 1961). They are all distinctly distinguished from one another. However, these species are very tiny and most of their morphological details can hardly be examined under microscope even by immersion, so that in some cases the exact morphology cannot be seen from these descriptions. Especially, C. lobiata may be referable to some other genus, as it is sharply distinguished from the other species. The present new species is closely related to C. subterranea in carapace shape, situation of radial pore canals, and armature of antenna and 2 distal podomeres of mandibular palp, but differs from this species in crenulated marginal teeth of hingement, form of muscular scars (?), fusion of the fourth and fifth podomeres of antennule, and in structure of maxillular palp (?) and furca.

\section{Genus Platymicrocythere Schornikov, gen. n.}

Type species: Platymicrocythere tokiokai Schornikov, sp. n.

Diagnosis: A deep excavation in the anteroventral region of carapace margin. Hingement lophodont. Vibratory plate of maxilla cylindrical, with a few apical rays. Furca with 2 setae.

Description: Antennule 5-segmented (4 and 5 podomeres united into an immovable segment), armed as: II, 1 svd; III, $1 \mathrm{sDd}$; IV, $1 \mathrm{sDm}, 3 \mathrm{sDd}, 1 \mathrm{svm}, 1 \mathrm{svd}, 1 \mathrm{sld}$; $\mathrm{V}, 3 \mathrm{~s}, 1 \mathrm{ts}$.

Exopodite of antenna 2-segmented, endopodite 3-segmented ( 2 and 3 podomeres united into an immovable segment), armed as: I, $1 \mathrm{svd}$; II, $1 \mathrm{svm}, 1 \mathrm{svd}, 2 \mathrm{sDm}$; III, $1 \mathrm{c}, 1 \mathrm{~s}$; seta of the first podomere rudimentary.

Masticatory part of mandible with 7 dents ( 2 to 5 serrated) and one seta at the base of anterior dent; palp armed as: I, 1 svd; II, 1 svd; III, 3 sDm, 1 sld, 2 svd; IV, $1 \mathrm{c}, 2 \mathrm{~s}$.

Maxillula with narrow masticatory lobes furnished with long, thin apical setae; palp 2-segmented, the basal podomere with 2 dorsodistal and one ventrodistal setae; the terminal podomere thin, inconspicuous and with 3 apical setae.

Remarks: This new genus differs from Cobanocythere Hartmann, 1959 in carapace shape, structure of hingement, armature of mandibular masticatory part and in structure of maxillular vibratory plate. It differs from Microcytheridea Hartmann, 1965 in structure of hingement, armature of mandibular masticatory part and maxillular vibratory plate. In addition to the type species, apparently, Cobanocythere labiata Hartmann, 1959 should be referred to this new genus. 


\section{Platymicrocythere tokiokai Schornikov, sp. n.}

(Fig. 5)

Holotype: Female, preparations No. 361-362.

Material: 2 females 0,29-0,30 mm long.

Description: Carapace strongly compressed dorsoventrally, with the ventral side concave in the posterior part, ratio between length, width and height 21: $7: 12$. Each shell projected out laterally to form a ventrolateral ridge. The anterior margin



Fig. 5. Platymicrocythere tokiokai, sp. n.

of left shell is narrowly rounded in the lower part and ascends dorsads in a sharp curve, continuing without any borders to the dorsal margin straight and slightly inclined posteriorly, the posterior margin produced into an angle, gently concave in the upper part and nearly truncate in the lower part; the ventral margin straight and covered almost completely by ventrolateral ridge, leaving only the anterior part exposed; anteroventral excavation deep; flange before this excavation is furnished with a dental row. Right shell lower and shorter than the left. The anterior margin 
rounded more narrowly, the dorsal margin slightly convexed and with cardinal angles faintly definable, the posterior margin nearly straight in the upper part, but narrowly rounded and serrated in the lower, anterior third of the ventral margin exposed outside the ventrolateral ridge which begins in the anteroventral region of shell, strongly convex upwards in the anterior part, but behind the excavation gradually descends posteriorly, though the basal line gently convexed downwards. The posterior end of the ridge is curved sharply upwards and forward in a loop; 3 short straight ridges are issued from the posterior part of ridge to the posterior margin of shell on left shell, but 2 on right shell. In the dorsal view carapace elongated oval, widest at posterior third. The anterior end bluntly pointed and with 2 small prominences on each side, the posterior end widely rounded and with a row of pointed prominences on each side; laterally smoothly inflated. Hingement lophodont, posterior tooth almost undefinable. Zone of concrescence wide, sparsely with radial pore canals which are mostly simple and branching only in the anteroventral and posteroventral regions. Normal pore canals sparse, large and simple. Frontal muscular scar consists of 2 elements, upper one tiny.

Length ratio between distal podomeres of antennule is $8: 7: 5: 5(3: 2): 6$; the ventrodistal seta of the second podomere reaches the base of the ventromedial seta of the fourth podomere, and the seta of the third podomere slightly exceeds the base of that seta on the next podomere. One of simple apical setae of the terminal podomere half as long as the other two.

Length ratio between endopodite podomeres of antenna is $6: 12(7: 5): 2$; the ventrodistal seta of the penultimate podomere thin, longer than the terminal podomere by $1 / 3$ of length of the last podomere. Apical claw thin, weakly curved; apical seta thick, $4 / 5$ as long as claw.

The penultimate podomere of mandibular palp strongly protruded in the middle part. Vibratory plate of maxillula with 8 apical rays.

Setal formula of maxillar basal podomere and thoracopods is: $0(?) 20 / 110 / 010$; apical claw long and weakly curved in these appendages.

Remarks: The present new species is related to Cobanocythere labiata Hartmann, 1959 , but differs from it in the details of structure of carapace and appendages.

\title{
Subfamily Paradoxostomatinae Brady et Norman, 1889
}

\author{
Genus Cytherois Muiller, 1884
}

\section{Cytherois zosterae Schornikov, sp. n.}

(Fig. 6)

Holotype: Male; preparations No. 488-489.

Material: Southeastern coast of Honshu Island, near the Seto Marine Biological Laboratory: 1 male 0,32 $\mathrm{mm}$ long, 1 male and 1 female $0,36 \mathrm{~mm}$ long. The Japan Sea: Posiet Bay, $5 \mathrm{~m}$ deep, shell; Trotza Bay, 0,5 $\mathrm{m}$ deep, from a grounded barge, 1 
male 0,33 $\mathrm{mm}$ long; 2,5 $\mathrm{m}$ deep, from Zostera blades, 1 male 0,30 $\mathrm{mm}$ long (holotype), 3 males $0,33 \mathrm{~mm}$ long and 51 females $0,33-0,35 \mathrm{~mm}$ long (paratypes). Ussuriysky Bay: Gornostay Bay, 3-4 m deep, from algae, 1 male 0,32 mm long.

Description: Male. Carapace small, elongated, weakly inflated; ratio between the length, height and width is 23: 7:6. The anterior margin of left shell very indistinctly separated from above, rounded a little more widely than the posterior;

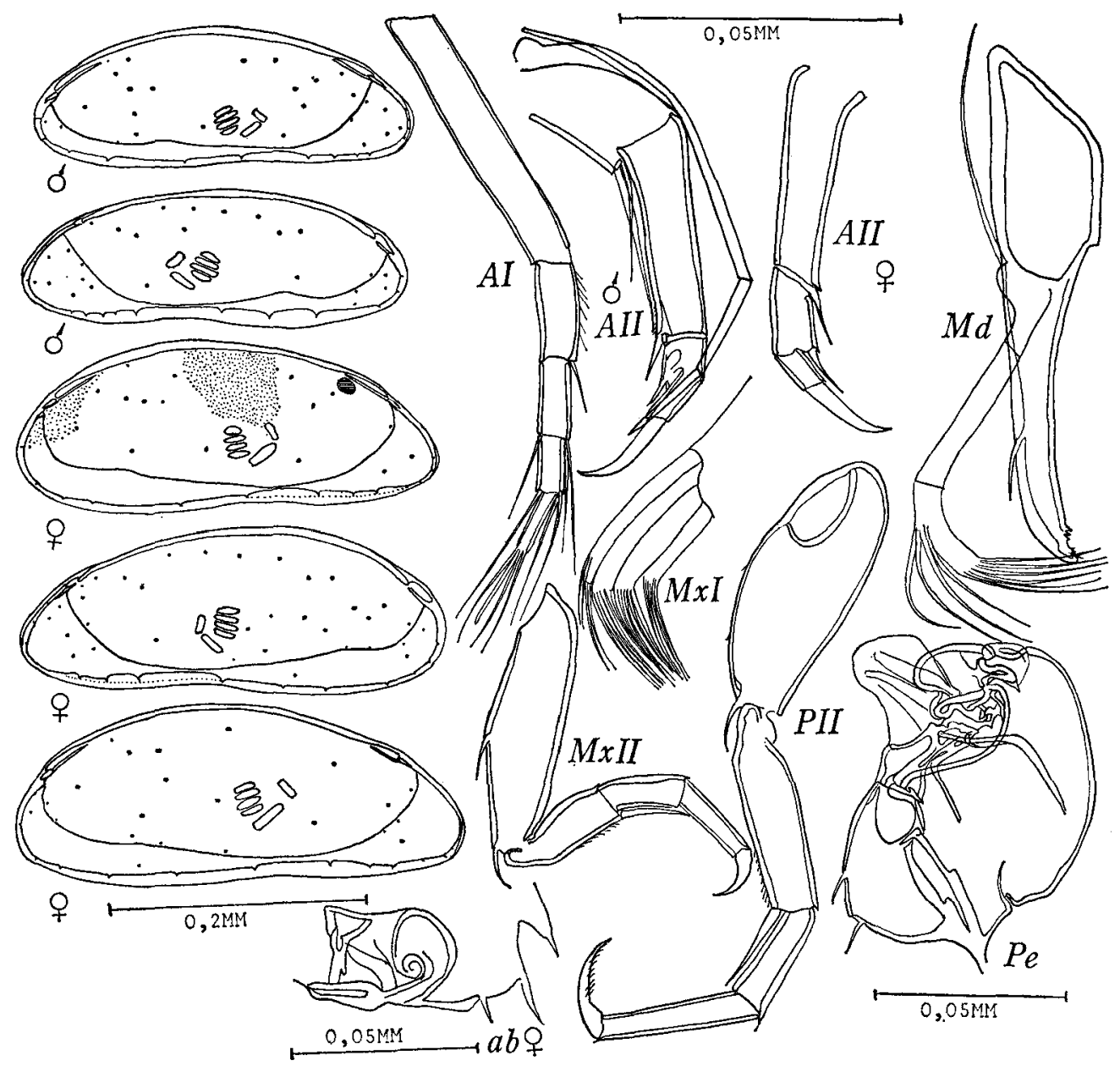

Fig. 6. Cytherois zosterae, sp. n.

the dorsal margin weakly and evenly convex, cardinal angles hardly noticeable; the ventral margin smoothly concave in the middle. The anterior and posterior margins of right shell rounded nearly equally and differentiated from above but indistinctly; the dorsal margin somewhat strongly convex; the ventral margin less concave than in left shell. In the dorsal view, carapace nearly equally pointed at both ends, lateral sides weakly inflated and each with a feeble angle slightly behind the middle. Zone 
of concrescence narrow, very short radial pore canals only in the anterior part of ventral margin. Normal pore canals small, sparse. Frontal and mandibular muscular scars singular, elongated and situated rectangularly each other.

Carapace transparent, 2 small dark grey spots respectively in the upper part at the level of the middle and in the posterior part of shell.

Antennule 6-segmented (the penultimate and 4th podomeres not completely divided), length ratio between the distal podomeres is $35: 12:(10: 7): 9$, the dorsodistal seta of the third podomere slightly exceeds the middle of the fourth podomere.

Antennal exopodite 3-segmented; length ratio between endopodite podomeres is $15: 30: 7: 6$, the larger ventrodistal seta of the first podomere reaches the end of the second podomere, the ventrodistal seta of the second podomere spine-shaped and as long as the third podomere, and the similar one of the third podomere exceeds the base of the apical podomere by $1 / 3$ of the length of the last podomere.

Mandibular masticatory part with 2 large marginal dents, each with a pair of small setac at the base, and with a seta behind the anterior dent. Palp 3-segmented, the terminal podomere with 4 dorsomedial and 6 apical setae.

Maxillular palp 2-segmented, basal podomere with 2 dorsodistal setae and distal one with 2 apical setae.

Setal formula of maxillar basal podomeres and thoracopods as: 111/110/010. Apical claw of these appendages rather stout and hook-shaped. Dorsodistal seta of the basal podomere of maxilla thin and stout. Thoracopod II considerably larger than maxilla.

Female. Carapace a little larger, higher and wider than in male; ratio between the length, height and width 26: 8: 7. The dorsal margin convexed more strongly than in male, descending more abruptly to the posterior margin at the posterior third than to the anterior margin.

Length ratio between antennal endopodite podomeres is 20: 15: 10:6; the ventrodistal seta of the second podomere thin. The posterior furcal seta twice as long as the lower one.

Remarks: The present new species is related to Cytherois pusilla Sars, 1928, but clearly differs from this in the shape of carapace and copulatory organ.

Genus Paradoxostoma Fischer, 1855

\section{Paradoxostoma brunneum Schornikov}

(Fig. 7B)

Paradoxostoma brunneum Schornikov, 1974, p. 207, fig. 41.

Material: 7 males 0,46-0,49 mm long; 7 females 0,49-0,56 mm long.

Distribution: The Japan Sea, Peter the Great Bay; shallow water of Shikotan Island (the Kurile Islands). 


\section{Paradoxostoma brunneatum Schornikov, sp. $\mathrm{n}$.}

(Fig. 7A)

Holotype: Male, preparations No. 1117-1118.

Material: One male 0,33 mm long, 3 females $0,42 \mathrm{~mm}$ long.

Description: Male. Carapace subrectangular, high and narrow; ratio between the length, height and width is 77: 14:9. The anterior margin of shell widely rounded, separable from above very vaguely; the dorsal margin gently convexed and slightly inclined to the anterior end; the posterior margin nearly plumb, smoothly concave in the lower half, and forming a distinct angle between it and the straight ventral margin. In the dorsal view, carapace with weakly inflated lateral sides; the anterior end weakly pointed, while the posterior end pointed in a beak-shape. Zone

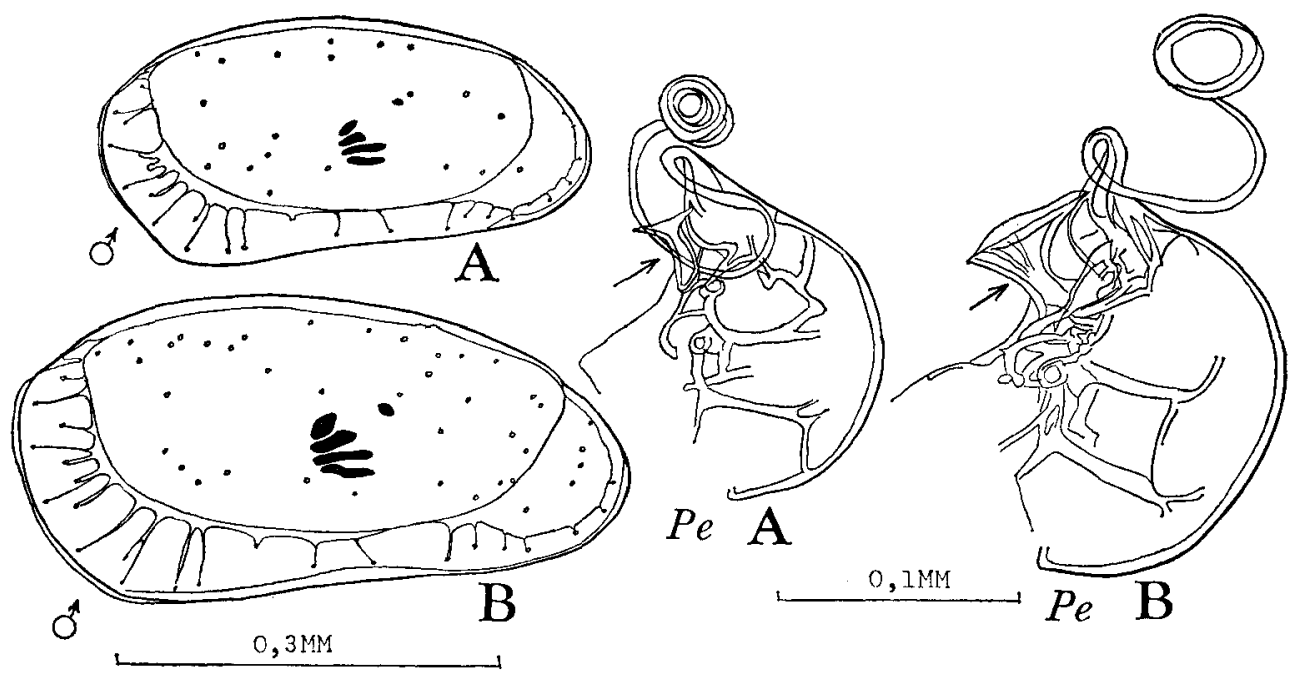

Fig. 7. A-Paradoxastoma brunneatum, sp. n.;

B-Paradoxostoma brunneum Schornikov.

of concrescence very wide, with thin long radial pore canals; 3 to 4 canals in the middle part of the posterior margin thickened at the base. Normal pore canals small, sparse. Hingement with very small and gentle terminal prominences (teeth) on left shell. Colour dark-brown.

Length ratio between distal podomeres of antennule is $30: 23: 27: 14: 7$. Exopodite of antenna 3-segmented, distal podomeres subequal in length. Length ratio between endopodite podomeres is 24:33:20:5; the ventrodistal seta of the first podomere is $2 / 3$ the length of the second podomere, a similar seta of the second podomere half as long as the third podomere, the seta of the penultimate podomere issued from the middle is as long as the terminal podomere; apical claw wide, slightly curved at the tip, and as long as the terminal podomere. 
Mandible with thin coxa, palp 3-segmented, with a single respiratory ray, the terminal podomere with 7 apical setae.

Maxillula without palp, anterior masticatory lobe with 5 setae, the second podomere with 4 setae, posterior lobe with 2 setae and $1 / 4$ as long as anterior ones. Brush-shaped organ cylindrical, with a bundle of apical hairs. Setal formula of basal podomeres of maxilla and thoracopods as: 110/110/010. The dorsodistal seta of the basal podomere of maxilla $2 / 3$ the length of the second podomere, apical claw thin, slightly curved.

Female. Carapace as in male, ratio between the length, height and width is $6: 3: 2$. Furca with 2 equal, thin and short setae.

Remarks: This new species resembles $P$. brunneum, but is separated from it by lesser size, different carapace form (widely rounded anterior margin, posterior margin concave in the lower part, and with a distinct angle between it and ventral margin), form of fixed lobe of copulatory organ and by ratio between some appendage structures.

\section{Paradoxostoma gibberum Schornikov, sp. $\mathrm{n}$.}

(Fig. 8)

Holotype: Male, preparations No. 1119-1120.

Material: 2 males and 3 females $0,42 \mathrm{~mm}$ long.

Description: Male. Carapace subtriangular, inflated, highest and widest in the middle. Ratio between the length, height and width 30: 12:9. The anterior margin of left shell rounded narrowly and evenly, a little wider than the posterior margin; the dorsal margin arched, weakly concave between it and the anterior margin, and with distinct posterior cardinal angle; the ventral margin slightly concave in the middle and convex near both ends. Anterior and posterior margins of right shell rounded more narrowly than in the left; the posterior margin weakly concave in the upper part; the dorsal margin convex more strongly and with expressed cardinal angles. In the dorsal view, sides of carapace evenly inflated, the anterior end narrowly rounded and the posterior end pointed in a beak-shape. Hingement lophodont, with large, pointed marginal teeth. Zone of concrescence extended along the ventral margin, with 3 large radial pore canals; the posterior margin with 2 pairs of larger canals. Line of concrescence nearly joined to the external margin near the anterior and posterior parts of the ventral margin. Normal pore canals large, dense.

Length ratio between the distal podomeres of antennule is 28: 30:20:8: 5 . Exopodite of antenna 2-segmented; length ratio between endopodite podomeres is 20:30:22: 5 ; the ventrodistal seta of the first podomere reaches the distal end of the second podomere, a similar seta of the second podomere reaches the middle of the third podomere, and the seta of the penultimate podomere short and weakly extended in the middle. Apical claw thin, twice as long as the terminal podomere, the second claw reduced to a vestigial seta hardly visible. 
Mandibular coxa stout, short; palp 3-segmented and with one respiratory ray, the terminal podomere with a dorsal seta near the distal margin and 6 terminal setae, of which 4 are of equal length and fused one another at the base, forming a tiny false podomere. Maxillula without palp, posterior masticatory lobe $1 / 4$ as long as anterior ones. Brush-shaped organ cylindrical, with a bundle of hairs on the anterior margin at the base in addition to the bundle of apical hairs. Setal formula of basal podomeres of maxilla and thoracopods as 110/110/010. The dorsodistal

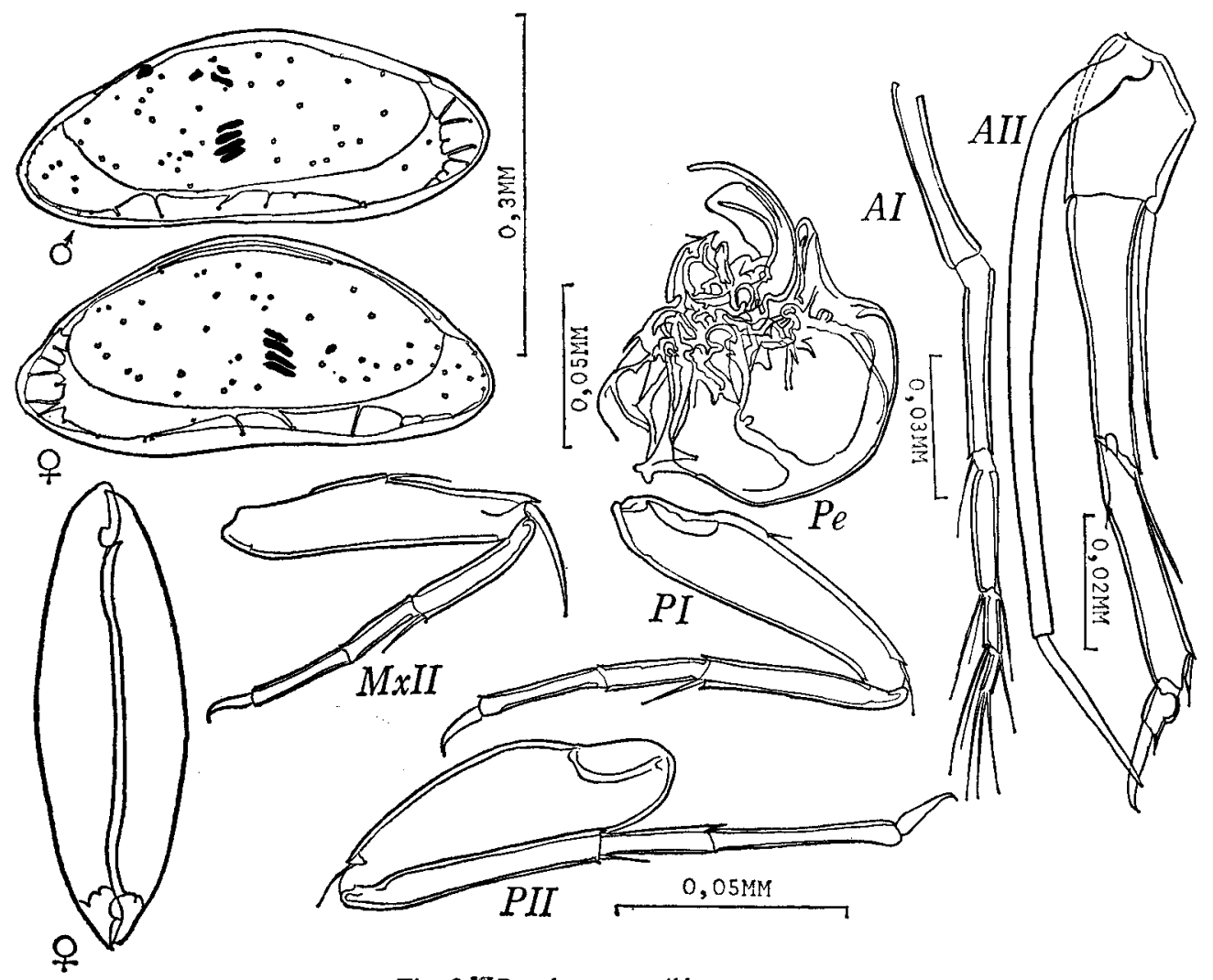

Fig. 8. PParadoxostoma gibberum, sp. $\mathrm{n}$.

seta of maxillar basal podomere weakly curved, sharply pointed, and 9/22 as long as the second podomere.

Female. Carapace with the dorsal margin strongly convex, more inflated than in male; ratio between the length, height and width 30:14: 10. Furca with 2 thin setae.

Remarks: The present new species is related to Paradoxostoma planum G.W. Müller, 1894, but differs from it in the structure of carapace and copulatory organ. 


\section{Paradoxostoma honssuensis Schornikov, sp. n.}

(Fig. 9)

Holotype: Male, preparations No. 1121-1122.

Material: 3 females $0,58 \mathrm{~mm}$ long and one of instar A-1.

Description: Carapace semi-lunate, strongly compressed laterally, with the dorsal side sharp as a knife-edge, highest and widest in the middle; ratio between the length, height and width is $4: 2: 1$. The dorsal margin evenly arched; the anterior and posterior margins subequally rounded widely in the lower part; the ventral margin almost straight, though slightly concave in the middle. In the dorsal view, carapace very narrow, lateral sides evenly inflated, the anterior end pointed slightly less than the posterior. Hingement with very narrow, smooth marginal teeth. Zone of

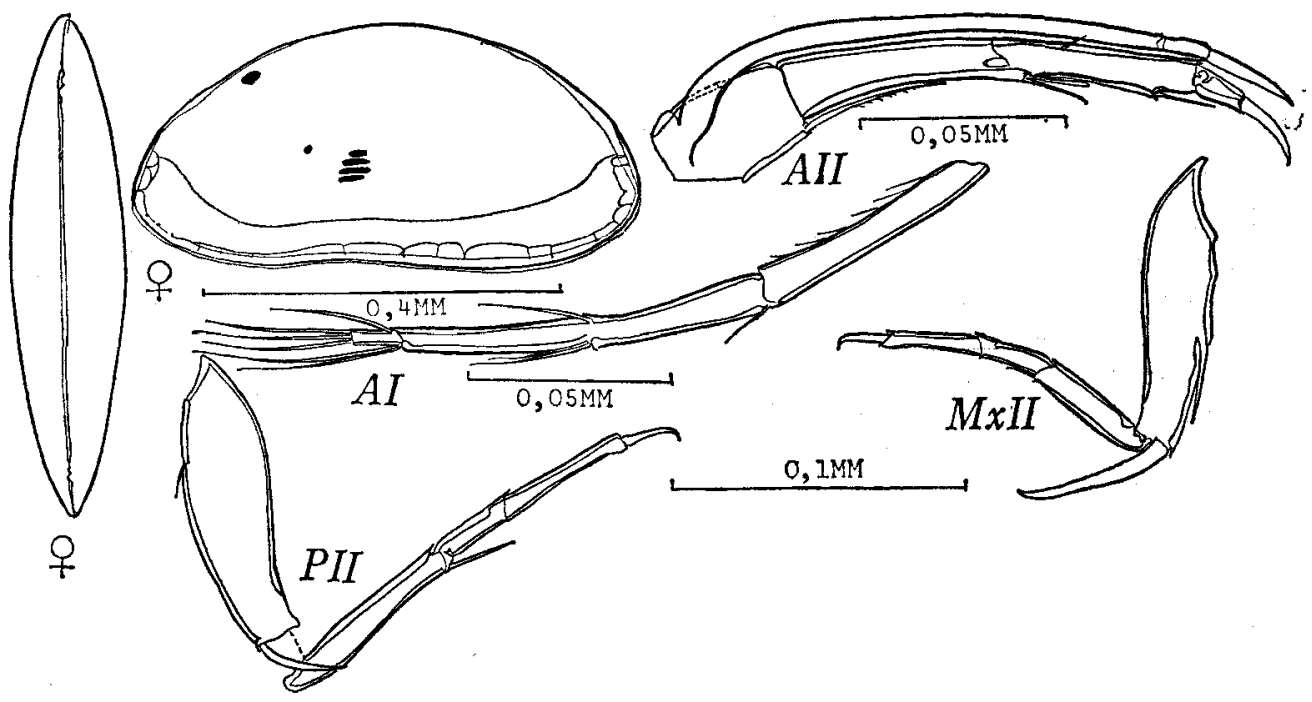

Fig. 9. Paradoxostoma honssuensis, sp. n.

concrescence narrow, sparsely with thin radial pore canals. Normal pore canals sparse, very small. Shell surface striated, colour black.

Length ratio between antennular terminal podomeres is 40:29:30:8:6. Antennal exopodite 3-segmented, the penultimate podomere very short. Length ratio between endopodite podomeres is $20: 38: 25: 10$; the ventrodistal seta of the first podomere exceeds the distal $3 / 4$ of the second podomere which is furnished with two ventrodistal setae, one tactile and another simple seta half as long as the third podomere; the ventrodistal seta of the penultimate podomere thin; apical claw a little longer than the terminal podomere.

Mandible coxa thin, long; palp 3-segmented, the terminal podomere with one short dorsal seta near the distal margin and 6 terminal setae. Maxillula without palp, the posterior masticatory lobe $1 / 3$ as long as anterior ones. Setal formula of 
maxilla and thoracopods as: 110/110/010; the dorsodistal seta of maxillar basal podomere stout and longer than the second podomere by $1 / 4$ of the length of the latter. Furca with 2 thin setae.

Remarks: This new species resembles Paradoxostoma arcuatum Hartmann, 1964, but differs from it in the details of carapace structure.

\section{Paradoxostoma aculeoliferum Schornikov, sp. n.}

(Fig. 10)

Holotype: Male, preparations No. 1123-1124.

Material: 15 females and 6 males 0,63 mm long, 4 specimens of instar A-1, 7 of instar A-2 and 8 of instar A-3.

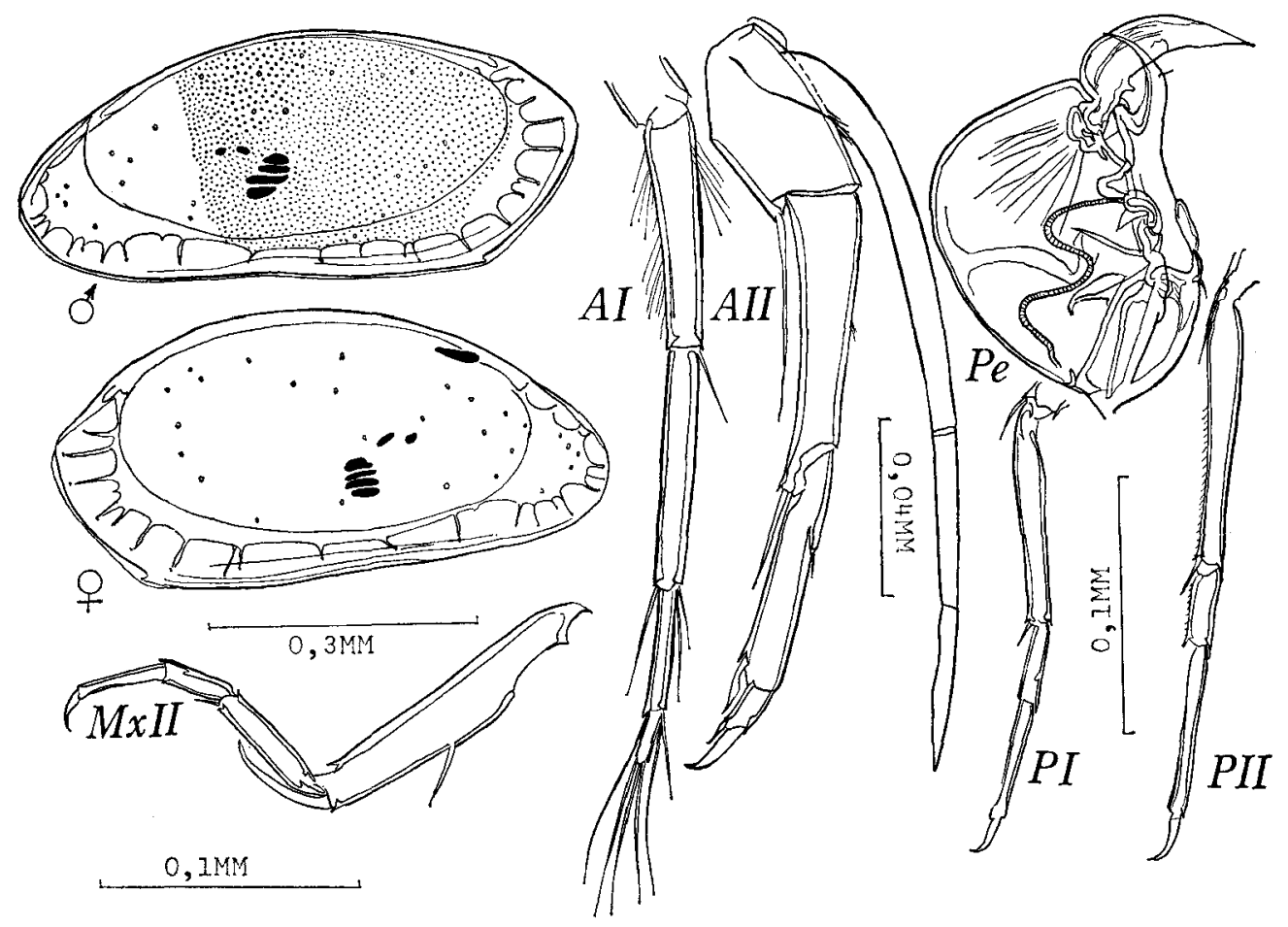

Fig. 10. Paradoxostoma aculeoliferum, sp. n.

Description: Male. Carapace roughly rhomboid, highest and widest a little behind the middle; ratio between the length, height and width is $45: 22,5: 15$. The anterior margin of left shell rounded widely and evenly; the dorsal margin convex gently and evenly; the posterior margin clearly defined, forming a rounded angle at the middle of the shell height; the ventral margin nearly straight, with a small spine on the border with the posterior margin. The dorsal margin of right shell convexed 
more strongly than in left shell, evenly concave near the anterior and posterior margins. In the dorsal view, carapace with evenly inflated lateral sides, the anterior end pointed weakly and the posterior end pointed in a beak-shape. Hingement lophodont, marginal teeth reduced almost completely and hardly noticeable. Zone of concrescence wide all along, with 3 typical radial pore canals near the middle of the anterior margin. Normal pore canals sparse and all nearly of the same size.

Colour of shell brown, with a large dark-brown spot in the middle part.

Length ratio between antennular distal podomeres is 40:40:40:20:7. Antennal exopodite 3-segmented, distal podomeres subequal in length. Length ratio between endopodite podomeres is 30:40:45:8; the ventrodistal seta of the first podomere $7 / 8$ as long as the second podomere, the seta of the second podomere reaching the distal $3 / 5$ of the third podomere, the similar seta of the penultimate podomere extended in the middle; 2 apical claws, lesser one half as long as larger one which is a little longer than the terminal podomere.

Mandibular coxa rather short, palp with one respiratory ray, 3-segmented, the terminal podomere with a bundle of apical setae. Maxillula without palp, posterior masticatory lobe $1 / 4$ as long as anterior ones. Brush-shaped organ cylindrical, with a bundle of hairs on the anterior margin at the base in addition to the bundle of apical hairs. Setal formula of basal podomeres of maxilla and thoracopods as: $110 / 110 / 010$; the dorsodistal seta of maxillar basal podomere stout, $6 / 7$ as long as the second podomere.

Female. The anterior margin of carapace rounded slightly more narrowly, the dorsal margin convexed more strongly than in male, ratio between the length, height and width is $45: 24: 17$. Carapace covered nearly wholly with a large darkbrown spot. Furca with 2 very small setae.

Remarks: This new species is similar in shape to Paradoxostoma ovulare Kajiyama, 1913, but sharply differentiated from it by the existence of a spine between the ventral and posterior margins.

\section{6a. Paradoxostoma aff. aculeoliferum Schornikov}

(Fig. 11)

One female $0,65 \mathrm{~mm}$ long found in the sample is similar to $P$. aculeoliferum in the

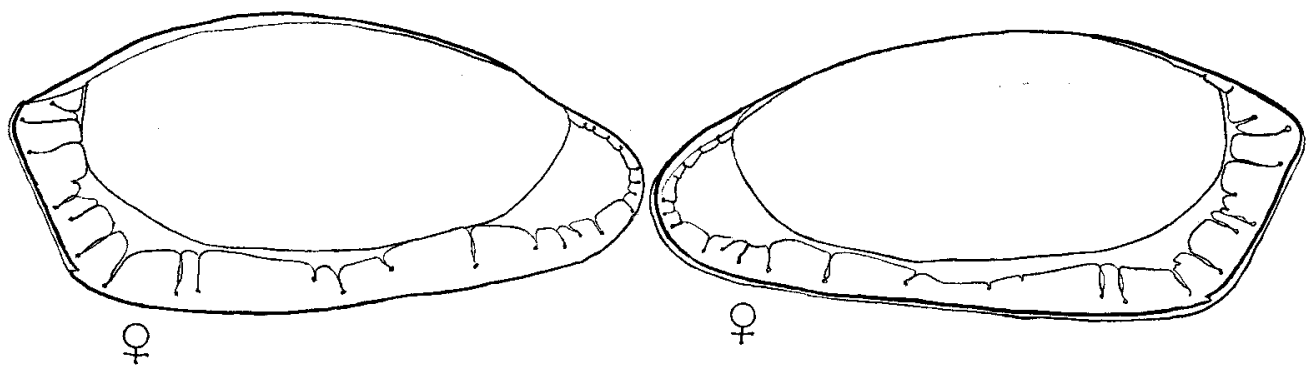

Fig. 11. Paradoxostoma aff. aculeoliferum Schornikov 
details of some shell structure, but differs from it in strongly expressed caudal angle and the nearly straight lower part of the posterior margin definable clearly. This is also similar to $P$. aculeoliferum in the structure of appendages. This might be a deformed specimen, though it is not impossible that it is an independent species closely related to $P$. aculeoliferum.

\section{Paradoxostoma micum Schornikov, sp. n.}

(Fig. 12)

Holotype: Female, preparations No. 1125-1126.

Material: 4 specimens 0,42 $\mathrm{mm}$ long, 2 dilapidated males $0,37 \mathrm{~mm}$ long, 4 larvae of instar A-1 and 2 of instar A-2.

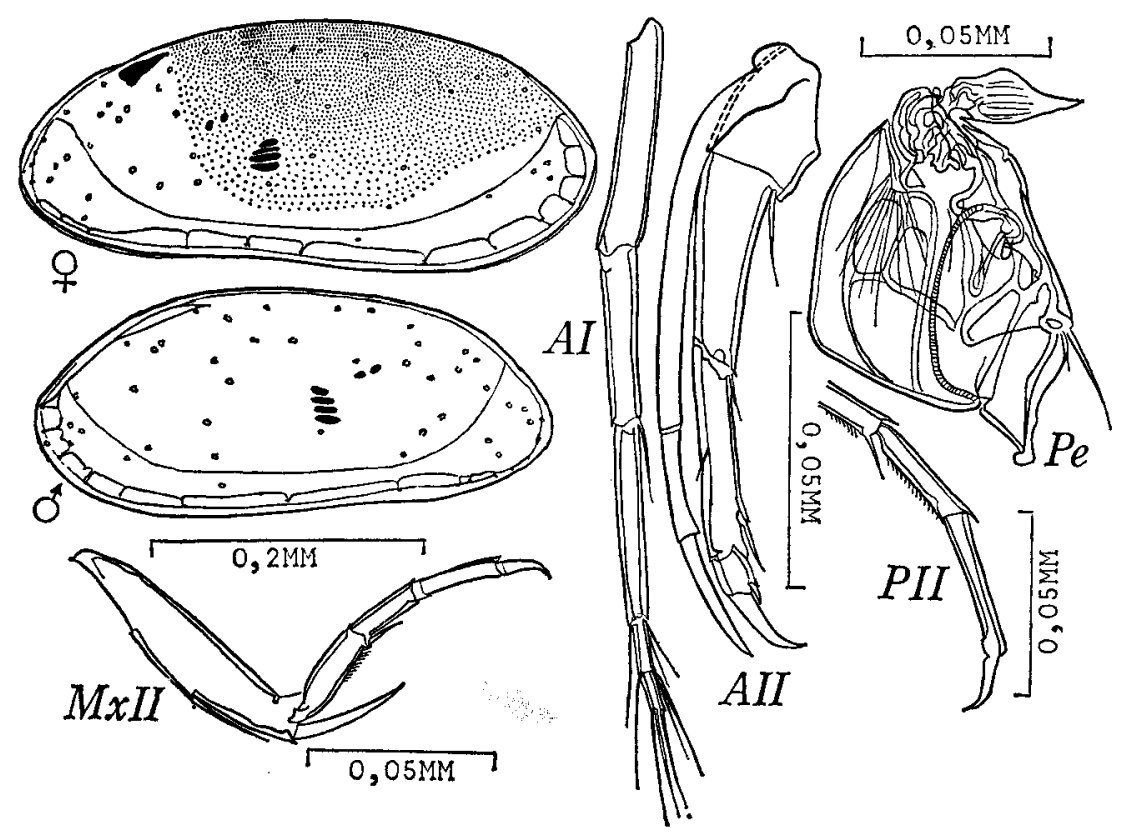

Fig. 12. Paradoxostoma micum, sp. n.

Description: Female. Carapace subelliptical, weakly inflated, highest and widest in the middle; ratio between the length, height and width is 15:7:4. The anterior margin of left shell rounded widely, separable indistinctly from above and below; the dorsal margin convex feebly and evenly; the posterior margin rounded more widely than the anterior margin, separable from above only vaguely; the ventral margin slightly concave in the middle. Anterior and posterior margins of right shell separated from above a little more clearly than in left shell; the dorsal margin convex most prominently at the posterior third, then lowered to the anterior margin 
more gently. In the dorsal view, carapace with evenly inflated lateral sides, the anterior end pointed more weakly than the posterior end. Hingement adont. Zone of concrescence narrow, sparsely with thin and evenly distributed radial pore canals. Line of concrescence joined to the outer margin at the anterior margin. Normal pore canals comparatively large.

A large dark spot along the dorsal margin in the middle part of carapace.

Length ratio between the distal podomeres of antennule is $30: 20: 25: 7: 5$. Antennal exopodite 3-segmented, distal podomeres subequal; length ratio between endopodite podomeres is $16: 25: 27: 5$, the ventrodistal seta of the first podomere $3 / 5$ as long as the second podomere, the similar seta of the second podomere $2 / 5$ the length of the ventral margin of the third podomere, the ventrodistal seta of the penultimate podomere thin; apical claw twice as long as the terminal podomere, the second claw rudimentary and very small.

Mandible coxa relatively short; palp without respiratory ray, 3-segmented and with 4 very long apical setae. Maxillula with rudimentary palp in the form of a short seta, posterior masticatory lobe $1 / 4$ as long as the anterior ones. Setal formula of basal podomeres of maxilla and thoracopods as: 110/110/010; the dorsodistal seta of maxillar basal podomere stout, a little longer than that of the second podomere. Furca with 2 thin setae, the posterior seta twice as long as the anterior one.

Male. Carapace a little lower than in female, ratio between the length, height and width is $27: 13: 8$. Brush-shaped organ short, with a bundle of apical hairs.

Remarks: The present new species is related to Paradoxostoma salvadorensis Hartmann, 1959, but clearly differs from it in the details of the structure of carapace and copulatory organ.

\section{Paradoxostoma faccidum Schornikov, sp. n.}

(Fig. 13)

Holotype: Male, preparations No. 1127-1128.

Material: 5 males 0,60-0,63 mm long, 6 females $0,64-0,68 \mathrm{~mm}$ long, 4 specimens of instar A-1 and 2 of instar A-2.

Description: Male. Carapace weakly inflated, subrectangular, and with the ventral margin steadily sloping down in the posterior part; ratio between the length, height and width is $45: 21: 13$. The anterior margin of left shell rounded very widely and evenly; the dorsal margin straight; the posterior margin widely rounded and clearly separated from below; the ventral margin convex in the posterior part, straight in the middle, and sloping up towards the anterior margin. The anterior margin of right shell clearly separable from above; the dorsal margin with expressed cardinal angle; the posterior margin indistinctly separated from above. In the dorsal view, carapace with evenly inflated lateral sides, the anterior end pointed slightly more weakly than the posterior end. Hingement adont. Zone of concrescence not wide, with thin and evenly distributed radial pore canals. Line of concrescence slightly 
approached in the middle part of shell to the external margin and joined to it in the anterior margin. Normal pore canals small, sparse.

Carapace translucent, with 2 bluish black transversal stripes respectively in the middle and posterior parts.

Length ratio between distal podomeres of antennule is $20: 15: 25: 5: 3$. Antennal exopodite 3-segmented, the penultimate podomere a little shorter than the terminal

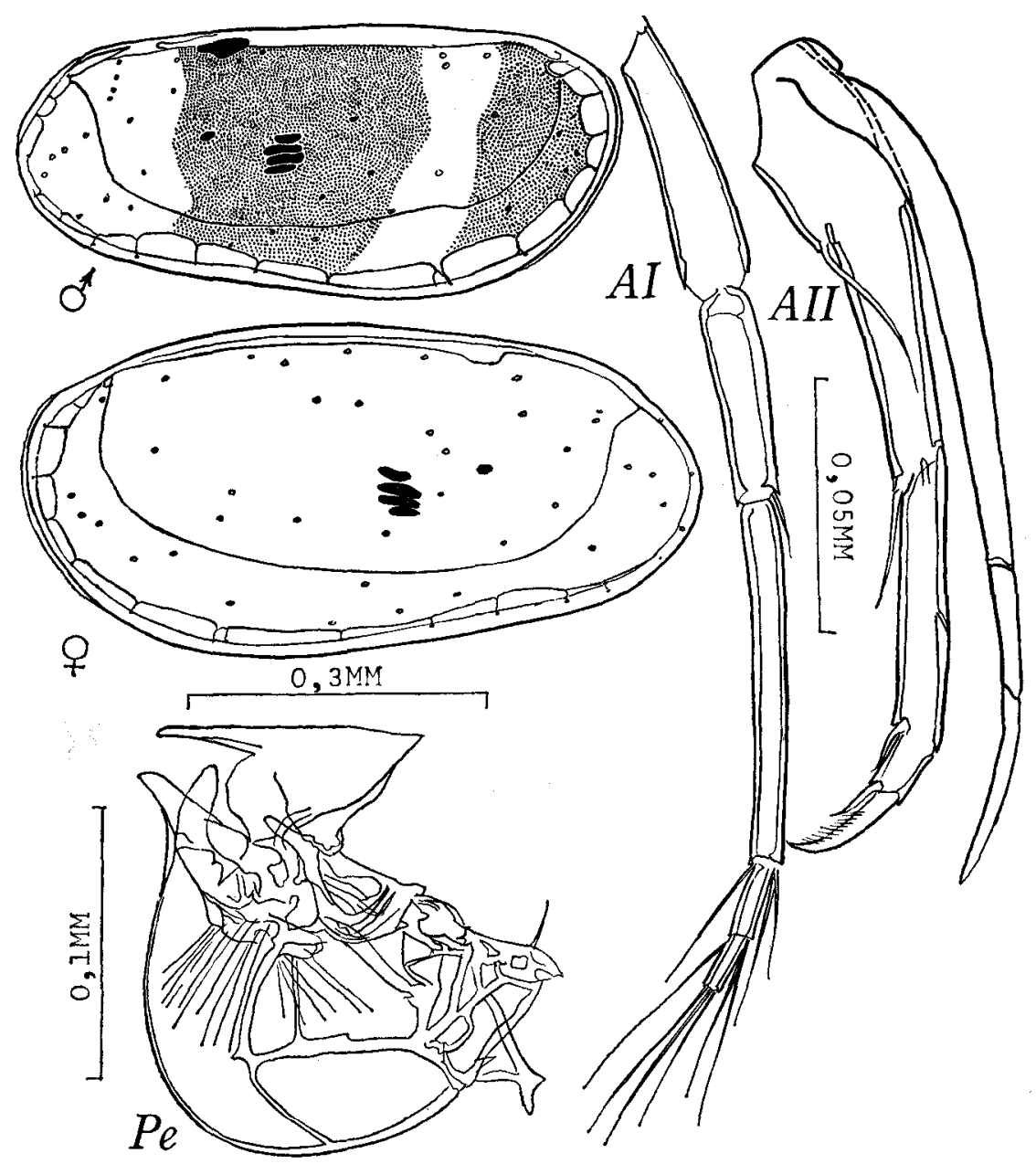

Fig. 13. Paradoxostoma flaccidum, sp. n.

one. Length ratio between endopodite podomeres is 25:37:43:10; the ventrodistal seta of the first podomere is $4 / 7$ as long as the second podomere, the similar seta of the second podomere reaches $4 / 9$ of the ventral margin of the penultimate podomere, the ventrodistal seta of the penultimate podomere thin; apical claw 1,3 times as long as the terminal podomere, the inner rudimentary second claw large, half as long as the outer one. 
Mandibular coxa of a moderate length, palp without respiratory ray, 3-segmented and with 6 terminal setae. Maxillula with rudimentary palp like a seta. Brushshaped organ short, wide, and with a small bundle of hairs on the anterior margin in addition to the large apical bundle. Setal formula of basal podomeres of maxilla and thoracopods as 110/110/010. The dorsodistal seta of the basal podomere of maxilla and the first thoracopod stout, that of the second thoracopod thin, the seta of maxillar basal podomere a little longer than the second podomere, but that of the basal podomere of the first thoracopod half as long as the second podomere. Four thick and 2 thin spines on the ventral margin of the third podomere of thoracopod II, and 10 thin spines on the terminal podomere.

Female. Carapace larger, higher and wider than in male, the posterior margin separated from below more vaguely; ratio between the length, height and width is 49: 25: 17. Furca with 2 thin long setae.

Remarks: This new species resembles Paradoxostoma rarum G.W. Müller, 1894, but clearly differs from it in the structure of carapace and copulatory organ.

\section{Paradoxostoma setoensis Schornikov, sp. n.}

(Fig. 14)

Holotype: Female, preparations No. 1129-1130.

Material: 2 females $0,7 \mathrm{~mm}$ long and one male $0,67 \mathrm{~mm}$ long, with the flesh semi-decomposed.

Description: Female. Carapace elongated, weakly inflated, highest at the posterior third and widest at the anterior third; ratio between the length, height and width is 25:11:9. The anterior margin of left shell rounded widely and evenly; the dorsal margin weakly convex, descending more gently to the anterior than to the posterior margin weakly cut off from above and rounded a little more narrowly than the anterior margin; the ventral margin weakly concave in the middle. The anterior margin of right shell weakly cutt off from above; the dorsal margin nearly straight, the posterior margin slightly concave in the upper part and weakly cut off from below, forming a rounded angle at the level of upper third of shell. In the dorsal view, carapace with equally pointed ends. Hingement adont. Zone of concrescence not wide, with thin radial pore canals, the pair of the canals at the posterior third with extended common base. Normal pore canals small, sparse.

Colour black with a bluish tint.

Length ratio between antennular distal podomeres is $35: 45: 43: 10: 5$. Antennal exopodite 3-segmented, distal podomeres subequal in length. Length ratio between endopodite podomeres $6: 7: 9: 2$; the ventrodistal seta of the first podomere reaches the base of the similar seta of the second podomere, which is $3 / 7$ as long as the ventral margin of the third podomere, the ventrodistal seta of the penultimate podomere thin; outer apical claw $1 / 3$ time the length of the terminal podomere, inner claw large, $2 / 3$ as long as outer one. 
Mandibular coxa not long; palp 3-segmented, without respiratory ray, with a bundle of the terminal setae. Maxillula with palp seta-shaped. Setal formula of basal podomeres of maxilla and thoracopods as: 110/110/010. The dorsodistal seta of the basal podomere of maxilla stout, a little longer than the second podomere. The penultimate podomere of thoracopod II with 7 thick and 3 thin spines on the ventral margin, the terminal podomere with a row of thin spines. Furca with 2 thin subequal setae.

Male. Carapace slightly lower and narrower than in female, ratio between

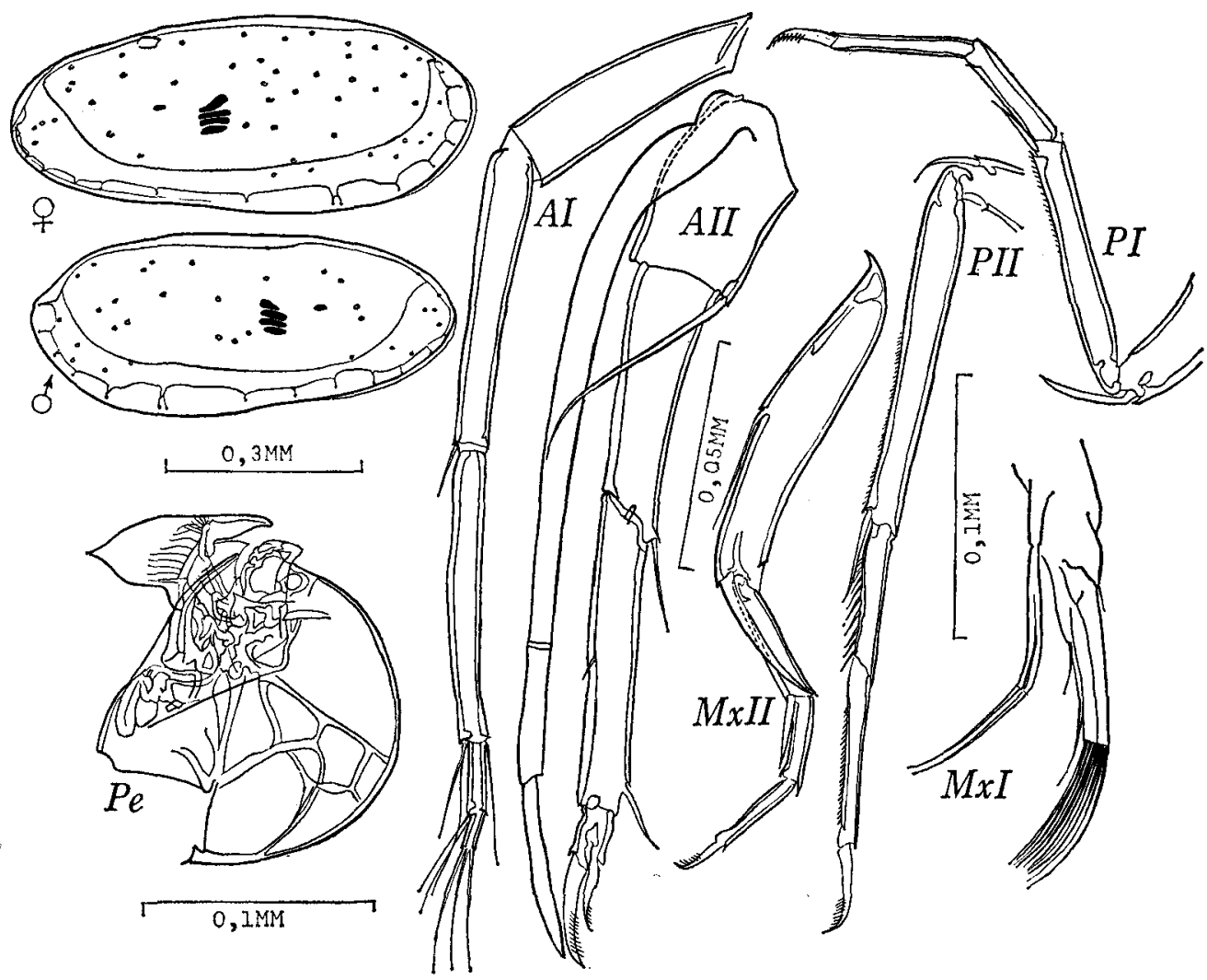

Fig. 14. Paradoxostoma setoensis, sp. n.

the length, height and width is $48: 21: 17$.

Remarks: The present new species is related to P. flaccidum, but clearly separated from it by the details of the structure of carapace and copulatory organ.

20. Paradoxostoma japonicum Schornikov, sp. n.

(Fig. 15)

Holotype: Male, preparations No. 1131-1132. 
Material: One male 0,40 $\mathrm{mm}$ long, with the flesh semi-decomposed.

Description: Male. Carapace strongly elongated subhexagonal, weakly inflated, highest at the posterior third and widest in the middle; ratio between the length, height and width is $36: 15: 10$. The anterior margin of left shell rounded narrowly and evenly; the dorsal margin nearly straight in the anterior part, anteriorly gently sloping down to the anterior margin, but posteriorly rather abruptly descending to the posterior margin from the highest point; the posterior margin cut off from above and below, rounded very narrowly at the level of the middle of the shell height; the ventral margin weakly concave in the middle, slightly ascending towards the anterior margin. The anterior margin of right shell cut off from above and below, narrowly

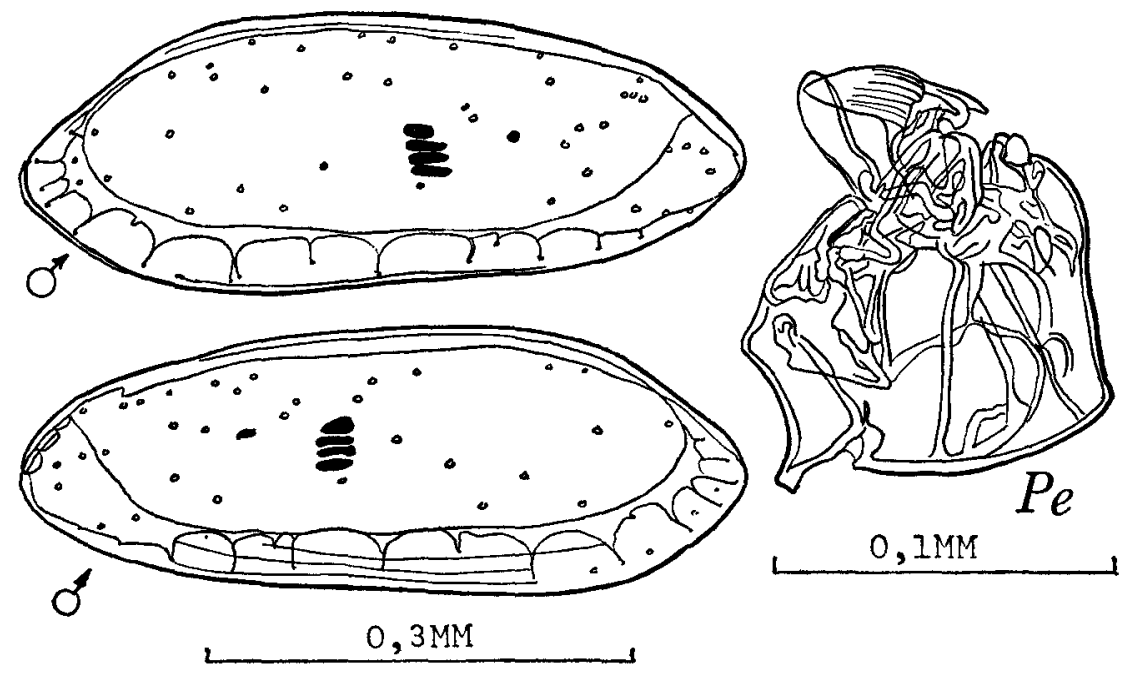

Fig. 15. Paradoxostoma japonicum, sp. n.

rounded in the middle. In the dorsal view, carapace with subequally pointed ends. Hingement adont. Zone of concrescence wide along the posterior to ventral margin, with thin radial pore canals; a group of 3 canals on the posterior margin. A moderate number of normal pore canals small.

Exopodite of antenna 3-segmented, distal podomeres subequal in length. Mandibular coxa not long, palp 3-segmented, without respiratory ray, with a bundle of apical setae. Brush-shaped organ short, wide, with a small bundle of hairs at the base on the anterior margin in addition to a large bundle of apical hairs. Other appendages not studied.

Remarks: The present new species is related to Paradoxostoma longum Hartmann, 1964 , but differs from it in the details of the structure of carapace and copulatory organ.

\section{REFERENCES}

Benson, R. H., 1964. Recent marine Podocopid and Platycopid Ostracodes of the Pacific. Pubbl. 
Staz. Zool. Napoli, v. 33 supp. p. $387-420,2$ text-figs.

Caraion, F. E., 1967. Fam. Cytheridae (Ostacode marine şi selmastrieocole). Fauna R.S.R. Crustacea (Ostracoda). v. 4, no. 10, p. 1-164, 43 figs.

Hanai, T., 1959a. Studies on the Ostracoda from Japan. 5. Subfamily Cytherinae Dana, 1852(emend). Tokyo Univ., Fac. Sci. Jour., sec. 2, v. 11, pt. 4, p. 409-418, pl. 28.

1959b. Studies on the Ostracoda from Japan. Historical review with bibliographic index of Japanese Ostracoda, Ibid., p. 419-439.

1961. Studies on the Ostracoda from Japan: Hingement, Ibid., v. 13, pt. 2, p. 345-377, 14 texst-figs.

1970. Studies on the Ostracoda subfamily Schizocytherinae Mandelstam. Journ. Paleont., v. 44 , no. 4 , p. $493-729$, pls. 107-108, 19 text-figs.

Hartmann, G., 1959. Zur Kenntnis der lotishen Lebensbereiche der pazifischen Küste von E1 Salvador unter besonderer Berücksichtigung seiner Ostracodenfauna. Kieler Meeresforsch., v. 15, no. 2, p. 187-241, pls. 27-48.

1963. Zur Phylogenie und Systemstik der Ostracoden. Z. zool. Syst. Evolutionsforsch., v. 1, no. $1 / 2$, p. 1-154, 32 figs.

1965. Ostracoden des Sublitorals, Tiel III. In Hartmann-Schröder, G. und Hartmann, G., Zur Kenntnis des Sublitoral der chilenischen Küste unter besonderer Berücksichtigung der Polychaeten und Ostracoden. Mitt. Hamburg. Zool. Mus. Inst. Bd. 62, p. 307-380, 131 figs.

Ishizaki, K., 1966. Miocene and Pliocene ostracodes from the Sendai Area, Japan. Tohoku Univ., Sci. Rept., 2nd ser. (Geol.), v. 37, no. 2, p. 131-163, 1 fig., 2 tables, pls. 16-19.

- 1968. Ostracodes from Uranouhi Bay, Kochi Prefecture, Japan. Ibid., v. 40, no. 1, p. 1-45, 17 figs., 1 table, pls. 1-9.

- 1969. Ostracodes from Shinjiko and Nakanoumi, Shimane Prefecture, Westen Honshu, Japan. Ibid., v. 41, no. 2, p. 197-224, 16 figs., 2 tables, pls. 24-26.

1971. Ostracodes from Aomori Bay, Aomori Prefecture, North. east Honshu, Japan. Ibid., v. 43, no. 1, p. 59-97, 8 figs., 4 tables, pls. 1-7.

Kajiyama, E., 1913. The Ostracoda of Misaki, Part 3. Zool. Mag., Tokyo (Dobutsugaku-Zasshi), v. 25, p. 1-16, pl. 1. (In Japanese).

Omastola, M. E., 1970, On structure and morphologic variation of normal pore system in recent cytherid Ostracoda (Crustacea). Acta zool. v. 52, no. 1-2, p. 115-124, pls. 1-3.

Reys, S., 1961. Recherches sur la systématique et la distribution des ostracodes de la région de Marseille. Rec. Trav. St. Mar. End., v. 22, no. 36, p. 53-109, 5 tables, pls. 1-11.

Schornikov, E. I., 1974. On the study of ostracods (Crustacea) from the intertidal zone of the Kurile Islands. Flora and Fauna in the Intertidal Zone of the Kurile Islands. Trans. no. 1, publ. "Nauka"' Siberian Branch, Novosibirsk, p. 137-214, 43 text-figs, 4 tables. (In Russian). 